7. Шнейдер Л.Б. Психология девиантного и аддиктивного поведения детей и подростков: учебник и практикум для академического бакалавриата. - М.: Юрайт, 2019. - 219 с.

8. Шалагин А.Е. Криминальная субкультура как угроза общественной нравственности // Библиотека криминалиста. Научный журнал. - 2015. - № 4(21). - С. 196-202.

9. Комлев Ю.Ю. Теории девиантного поведения: учебное пособие. - Казань: КЮИ МВД России, 2013. - $302 \mathrm{c}$.

10. Гилинский Я.И. Девиантология: социология преступности, наркотизма, проституции, самоубийств и других «отклонений». - СПб.: Юридический центр Пресс, 2007. - 528 с.

11. Клейберг Ю.А. Психология девиантного поведения: учебник и практикум для вузов. - М.: Юрайт, 2019. - 290 c.

12. Кабачков В.А., Куренцов В.А., Зюзин Э.А. Профилактика наркомании средствами физической культуры и спорта: учебное пособие. - М.: Академия, 2015. - 224 с.

13. Самыгин П.С., Самыгин С.И., Кротов Д.В. Профилактика девиантного поведения молодежи: учебное пособие для академического бакалавриата / под общ. ред. П.С. Самыгина. - М.: Юрайт, 2019. - 284 c.

14. Шалагин А.Е. Криминологическая характеристика и предупреждение подростково-молодежной преступности // Библиотека криминалиста. Научный журнал. - 2016. - № 4(27). - С. 113-119.

\title{
Vlasova I.V. \\ The synergetic approach as the basis for the formation of the value of a foreign language among students of a technical university
}

Samara State Technical University

(Russia, Samara)

doi: $10.18411 / l j-12-2019-178$

idsp: ljournal-12-2019-178

\section{Abstract}

The article considers the synergetic approach as the basis for the formation of the value of a foreign language among students of a technical university. Taking into account the important role of the synergetic approach for the formation of a value-related attitude towards a foreign language among students of a technical university, the teachers of the Department of Foreign Languages of the Samara Technical University developed the textbook "Chemistry in nanosphere," which is based on the synergetic approach. The article discusses the structure of the textbook and guidelines for working with the textbook for teachers.

Key words: university students, value of a foreign language, synergetic approach, skills, textbook, educational task.

Currently, the requirements for professional, general cultural and especially foreign language training of future specialists are constantly increasing, therefore it is necessary to develop scientifically based approaches and methods for training. The education system is evolving, so it has the ability to self-organize. Synergetics studies the processes of any complex open systems [1, 2]. It does not offer specific patterns for resolving issues, but helps to highlight the general and ask questions. Application of the laws of synergetics to the education process gives a chance to bring it out of equilibrium, since at present the education process is very static.

In addition, education often does not have time to meet modern requirements, especially recently, when the flow of information in many areas of knowledge is growing rapidly in a number of cases, such as high technology. This affects many areas of life, in particular the rapid surge in computer technology and especially Internet technology has caused significant changes in the transmission of information. These factors must be taken into account when forming the concept and provisions ensuring the development of educational technologies.

Synergetics is able to give recommendations on the management of the educational process. According to V.G. Vinenko, in pedagogy the time has come to apply synergetics for 
a long time, since it interprets the processes of education in a new way and reveals their nonlinear nature. [3]. In our case, this is the formation of the value attitude of students of a technical university to the study of a foreign language. For an adequate understanding of the essence of the process of language acquisition and the optimal organization of the corresponding process, it is advisable to study it from the standpoint of synergetics. We have in mind the study of such factors as the role of the personality of the teacher and student, the freedom of their choice of the trajectory of behavior, the search for attractors and process control parameters.

The process of teaching a foreign language is considered from the point of view of synergetics as the management of an individual's self-learning. The students' need for selfdevelopment in the process of learning a foreign language is the basis of their cognitive activity. The teacher assesses the correctness or incorrectness of the implementation of educational tasks, organizes the learning process and transfers information to students.

Teaching university students a foreign language means not only the process of accumulating certain knowledge, but also the awareness of the need to acquire new knowledge. In this regard, the synergistic approach in the process of teaching a foreign language contributes to the formation of students' value attitude to a foreign language. The following reasons contribute to this: firstly, a foreign language is used as a means of obtaining foreign scientific, technical, cultural and socio-economic information, secondly, as a means of intercultural and foreign language communications with foreign scientists and specialists, with scientists and cultural workers, and thirdly, as a means of using the resources of the global Internet in the relevant subject areas of knowledge. [4].

Taking into account the important role of the synergetic approach for the formation of a value-related attitude towards a foreign language among students of a technical university, the teachers of the Department of Foreign Languages of the Samara Technical University developed the textbook "Chemistry in nanosphere." [5]. It is intended for professionallyoriented teaching English to third-year students of the Faculty of Chemical Engineering , training areas: chemistry, physics and mechanics of materials (training profile: functional, structural materials and nano materials). The main purpose of the textbook is the formation and improvement of reading and translation skills in the specialty in order to obtain information based on the assimilation of general technical and terminological vocabulary, as well as the development of speaking and writing skills and the formation of the value of a foreign language among students of a technical university.

The texts used in the textbook are taken from the Internet and partially abridged and adapted by the authors. The variety of texts and their content model the conditions of the real information retrieval activity of the future chemical engineer.

The textbook has a clear structure. It consists of 10 units, each has a specific structure and consists of 6 blocks: Before you read (pre-text exercises), Reading, Grammar, Speaking, Writing, Project Assignment. The appendix gives a brief grammar reference and terminological dictionary.

The authors of this textbook also developed a number of guidelines for a teacher to teach students different types of tasks in the textbook "Chemistry in nanosphere".

So, for example, when working with a text, the student is advised to memorize vocabulary using two-way translation (from English to Russian, from Russian to English) using different ways of writing vocabulary (word list, notebook, dictionary, card index).

To consolidate the vocabulary, it is advisable to use examples of the use of words and phrases in sentences, as well as word-building and semantic relations of memorized words (cognates, synonyms, antonyms). Each unit text is given a list of words and terms that are used in the text.

The student must write out these words, find the translation in the dictionary and choose the correct meaning from the possible ones. Many words are ambiguous, i.e. have several meanings, therefore, when searching for the meaning of a word in a dictionary, 
students must read the entire dictionary entry and select the translation that matches the sentence. In pre-text exercises, a simple question is proposed on the topic of the section in order to find out what information students have in this field. Discussion of this issue helps to penetrate the subject of the main text and arouse interest among students. Before reading the main text, it is also suggested that you first familiarize yourself with the frequency vocabulary on this topic, find the words in the text and in the dictionary. It is important to explain to students that not individual words, not grammatical constructions and other means of the original language are translated, but the integral content of the original. [6,7]. During the second stage, one linguistic form is replaced by another. What students perceived in English, they must express in Russian, i.e. using another system of conventional signs, which has its own laws. Full translation is the main form of technical translation. A step-by-step instruction is given when completing a full translation:

1. Before starting the translation, students must read the entire text, paragraph, or finished part of the text; try to understand the general content of the text.

2. Read the text a second time on individual sentences, understand the syntactic structure and meaning of each sentence. Translate text on sentences.

3. If the syntactic structure of the sentence is not clear and the students did not understand the meaning of the sentence, it is necessary to do a grammatical analysis: determine the type of sentence, find the subject, predicate and secondary members. If the sentence is complex, it is necessary to find the main and subordinate clause, based on formal signs.

4. When translating a subsequent sentence, it is necessary to constantly keep in mind the meaning of the previous sentence, otherwise the logical connection between the individual sentences is lost.

5. Students should avoid literal translation and try to convey the idea of the original by means of their native language, without violating its syntactic structure.

The Grammar block provides suggestions for translation on one of the studied grammatical topics: passive voice, participle, infinitive, gerund. Grammar exercises are based on learning the rule and constructing a speech cliche using this rule. The sequence of actions with grammar material is as follows:

1. learn the rule

2. search for a given grammatical phenomenon or structure in the text, an explanation of the meaning in which it is used in this context.

3. perform transformation exercises, guided by the rule.

4. translate exercises from the mother tongue into a foreign language.

The purpose of the Project Assignment task is to develop students' independent work skills, oral and written presentation of their own thoughts. It is focused on the development of cognitive skills of students, the ability to independently construct their knowledge, navigate the information space, and develop critical thinking. Projects can be very diverse in scope, and their result in our case is the creation of a presentation. Stages of work on the project include the following: selecting a topic, formulating a variant of the problems, assigning tasks to groups, group or individual development of the project, presenting the project, involving a collective discussion. To complete this task, the student must independently consider the question (problem) to which he is going to find the answer during his research and present the final work on the unit in the form of a Power Point presentation.

Each unit provides a task for the development of speaking skills. Students are invited to write a summary of the text they read using active vocabulary.

Each unit provides a task for the development of writing skills. Students are invited to formulate in writing the main idea of the unit text and express it in 3-4 sentences. At the same time, it is necessary to process the material for presentation, taking into account the individual 
capabilities and preferences of the student, namely: to replace words difficult for spelling with well-known lexical units.

As a result of working with the presented textbook, students gain knowledge about the basic grammatical phenomena characteristic of professional speech, methods of translating literature by specialty, acquire the ability to search for new information when working with texts from educational, scientific, technical and reference literature, to perform written assignments, master the skills of oral speech and professional communication according to the profile of the specialty, reading and writing skills. And the synergetic approach that the textbook is based on helps a lot to form the value of a foreign language among students of a technical university.

$$
* * *
$$

1. Haken G. Synergetics: Hierarchies of instabilities in self-organizing systems and devices: Per. from English M.: Mir, 1985. p. 423.

2. Lamzin S.A. Methodological principles as the basis of the theory of teaching foreign languages (synergistic aspect). Abstract. dis. Cand. ped sciences. Ryazan, 2002. p. 55.

3. Vinenko V.G. Synergetics at school // Pedagogy, 1997. - No. 2. p.55-60.

4. Nesterenko V. M., Ionesov V. I. Man in the system of spatio-temporal relationships: projections and challenges of sociocultural communication. - Bulletin of Samara State Technical University. Series "Psychological and Pedagogical Sciences", No. 2 (20) 2013.p. 142-148.

5. Banartseva A.V., Vlasova I.V. Chemistry in nanosphere. Textbook. Samara: Sam. tech. un-ty, 2019. p. 100 .

6. Kurlov A.B. The basics of communication theory. Ufa: RIO of BashSU, 2002.p. 124.

7. Vasilik M.A. The basics of communication theory. M .: Gardariki, 2007.p.617. 